\title{
IMAGING CONTINENTAL SHELF SHALLOW STRATIGRAPHY BY USING DIFFERENT HIGH-RESOLUTION SEISMIC SOURCES: AN EXAMPLE FROM THE CALABRO-TYRRHENIAN MARGIN (MEDITERRANEAN SEA)*
}

\author{
Eleonora Martorelli ${ }^{1}$, Francesco Latino Chiocci ${ }^{1}$ and Luciana Orlando ${ }^{3}$
}

${ }^{1}$ Università degli Studi di Roma 'La Sapienza' Dipartimento di Scienze della Terra CNR - Istituto di Geologia Ambientale e Geoingegneria

(P.le A. Moro 5, 00185 Rome, Italy)

eleonora.martorelli@uniroma1.it; francesco.chiocci@uniroma1.it

${ }^{2}$ Università degli Studi di Roma 'La Sapienza' Dipartimento di Idraulica, Trasporti e Strade (Via Eudossiana 18, 00184 Rome, Italy) luciana.orlando@uniroma1.it

\section{A B S T R A C T}

High-resolution seismic reflection profiles of the Calabro-Tyrrhenian continental shelf were collected using different seismic sources (Sub-Bottom Profiler, Uniboom, Sparker 0.5-1-4.5 kJ). Noticeable differences and results were obtained both from a geophysical and geological-interpretative point of view. The availability of different sources permitted the definition of the most suitable seismostratigraphic characterization in terms of resolution, penetration and acoustic facies. Very high resolution stratigraphy was defined through profiles produced by different seismic systems used in parallel. This permitted the application of sequence-stratigraphy concepts with the reconstruction of a thick postglacial depositional sequence, formed by a transgressive and a high-stand systems tract. The thickness distribution of postglacial deposits reveals that the main depocenter $(55-65 \mathrm{~m})$ is located offshore of the Coastal Range, along a stretch of coast supplied by several small and seasonal streams ("fiumare") and characterized by the lack of a coastal plain. This suggests the greater efficiency of sediment supply and bypass in this area relatively to sectors located offshore of the main rivers. The transgressive systems tract, usually thin or nearly absent, is particularly well developed (up to $33 \mathrm{~m}$ ) and is composed of up to three parasequences with a retrogradational stacking pattern. The high-stand systems tract, up to $30 \mathrm{~m}$ thick, is made up of two parasequences and has a quite regular geometry and acoustic facies.

\section{RESUMO}

Perfis de reflexão sísmica de alta resolução da plataforma continental tirreniana de Calabro foram obtidos utilizando-se recursos sísmicos diversos (Perfilador de Sub-superfície, Uniboom, Sparker 0.5-1-4.5 kJ). Diferenças evidentes foram encontradas sob o ponto de vista geofísico e geológicointerpretativo. A disponibilidade de diferentes fontes permitiu a definição de uma caracterização sismo-estratigráfica mais acurada em termos de resolução, penetração e facies acústica. Uma estratigrafia de resolução bastante alta pôde ser obtida através de perfis produzidos por diferentes sistemas sísmicos utilizados em paralelo. Este fato possibilitou o emprego de conceitos de sequênciaestratigrafia para a reconstrução de uma espessa sequência deposicional pós-glacial formada por um trato de sistemas transgressivo e de nível de base alto. A espessura dos depósitos pós-glaciais revela que o principal centro de deposição $(55-65 \mathrm{~m})$ está localizado ao largo da serra costeira, ao longo de uma costa distendida e alimentada por pequenos filetes sazonais ("fiumare"), sendo caracterizado pela falta de uma planície costeira. Os dados sugerem a existência de um suprimento de sedimentos bastante eficiente nessa área, em relação a setores localizados ao largo dos rios principais. $\mathrm{O}$ trato de sistemas transgressivo, geralmente estreito ou ausente, é aqui particularmente bem desenvolvido (acima de $33 \mathrm{~m}$ ) e composto por até três parasequências com padrão de empilhamento retrogradacional. O trato de sistemas de nível de base alto, até $30 \mathrm{~m}$ de espessura, é composto por duas parasequências e apresenta geometria e facies acústica extremamente regulares.

Descriptors: Tyrrhenian Sea, Continental shelf, Postglacial deposits, Resolution and penetration, Seismic and sequence stratigraphy.

Descritores: Perfis de reflexão sísmica, Caracterização sismo-estratigráfica, Sequência deposicional pós-glacial, Plataforma continental tirreniana de Calabro.

(*) Paper presented at the INTERNATIONAL GEOLOGICAL CORRELATION PROGRAM PROJECT NO. 526 - RISKS, RESOURCES, AND RECORD OF THE PAST ON THE CONTINENTAL SHELF: MINING LATE QUATERNARY GEOLOGICAL EVIDENCE, 2., 2008, Natal, UFRN 


\section{INTRODUCTION}

The information obtained from different high-resolution seismic sources is here defined by means of a detailed seismo-stratigraphic analysis of the most recent deposits of the southeastern Tyrrhenian continental shelf, along a coastal stretch of $100 \mathrm{~km}$ in length (Fig. 1a).

This article seeks to stress the interdependence of data acquisition and seismostratigraphic interpretation in a continental shelf environment. Even in applied studies, such as site and
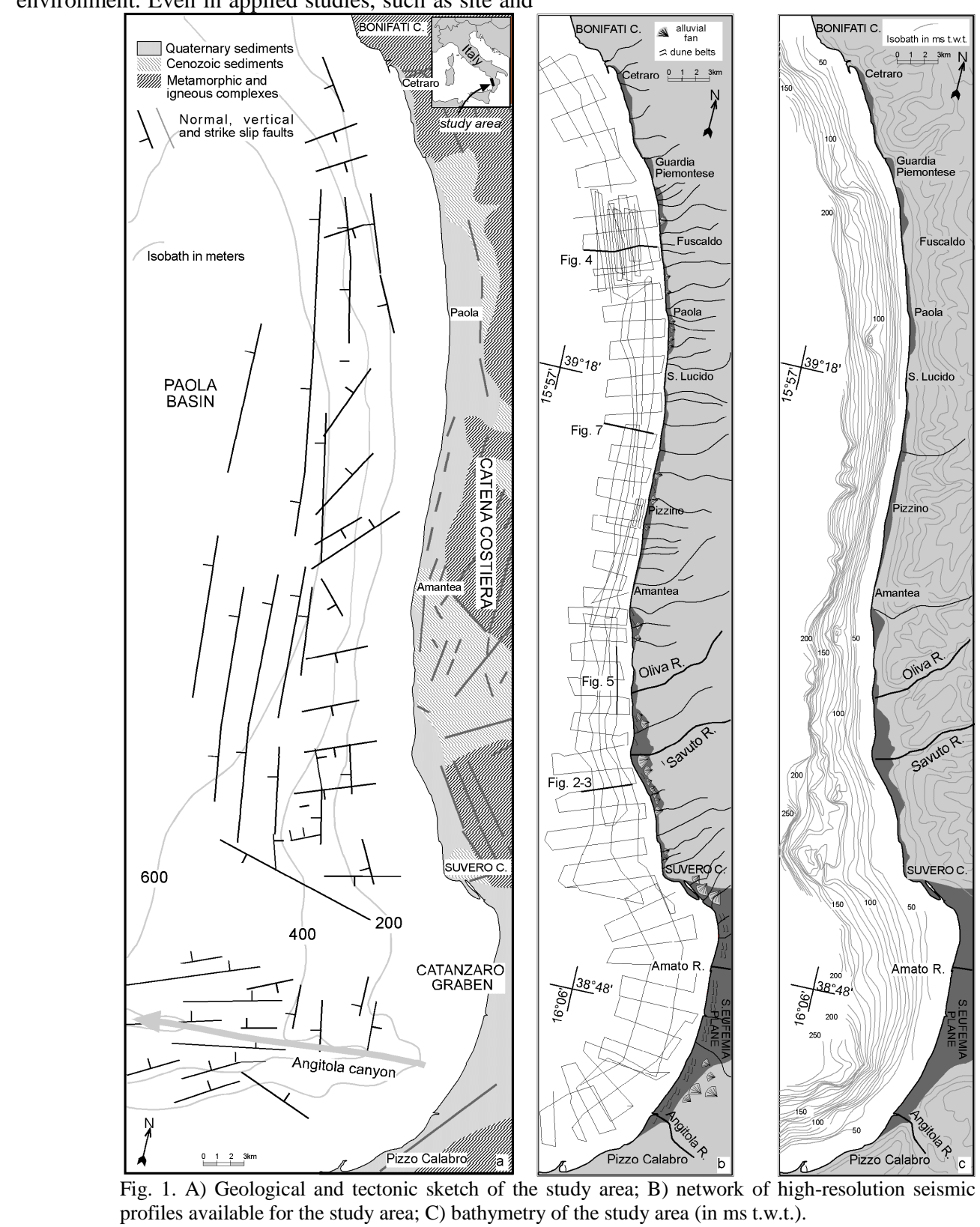

Fig. 1. A) Geological and tectonic sketch of the study area; B) network of high-resolution seismic profiles available for the study area; C) bathymetry of the study area (in ms t.w.t.). cable route surveys, the prospection of mineral resources and environmental assessment, the relationship between the methods and achievable interpretative results is a key point that needs to be precisely defined at the beginning of the research project.

This study will highlight the importance of coupling very high-resolution techniques to relatively high-penetration instruments and the differences arising in the definition of acoustic facies when different sources are used. 
As is well-established in the scientific literature, it is possible to apply advanced interpretative procedures (i.e., sequence stratigraphy) to depositional bodies as thin as a few meters, formed during a few thousand years. Thus even units with very small differences in reflector configuration, external form and acoustic facies, can be differentiated and characterized so as to obtain a precise geological interpretation. For this reason we will deal with both the geological and the geophysical aspects in terms of their mutual relationships, rather than deepen the specific geological/geophysical fields - for which one may refer to the more specific literature.

A complete review of seismic source characteristics and signatures may be found in Trabant (1984), Verbeek and McGee (1995), Mosher and Simpkin (1999), and McGee (2000).

The definition of sequence stratigraphic principles is given in Vail et al. (1977), Posamentier and Vail (1988), Van Wagoner et al. (1988), and Posamentier et al. (1992). The application of sequence stratigraphic principles has been shown to be particularly effective in the interpretation of highresolution seismic data from this area (CHIOCCI et al., 1989). This has also been demonstrated for other areas by Tesson et al. (1993), Hernandez-Molina et al. (2000), Trincardi and Correggiari (2000), and Lericolais et al. (2001), among others.

The notable expansion of the stratigraphic column in the study area allows the full use of highresolution seismics, making it possible to produce a precise definition of many sedimentary units, of even slight dimensions, deposited over the last 20,000 years. In this way, the complex nature of the Postglacial depositional sequence is defined. Although these deposits are often considered to be one single undifferentiated stratigraphic unit, they actually register a complete history of paleo-environmental variations related to postglacial eustatic phases, essentially one of sea level rise and high-stand.

\section{Geological Framework and Shelf STRATIGRAPHY}

The study area is the continental shelf between Bonifati Cape and Pizzo Calabro (Fig. 1a). It belongs to the Calabro-Tyrrhenian continental margin which includes the Coastal Range, bordered by a narrow coastal plain, a narrow and steep continental shelf and the continental slope. The Coastal Range, consisting of "Alpine" crystalline complexes, overthrusts the "Apennine" sedimentary units, is characterized by uplift rates of up to $1 \mathrm{~mm} / \mathrm{yr}$ which occurred during the upper Pleistocene (COSENTINO; GLIOZZI, 1988; WESTAWAY, 1993). In response to the strong uplift, land areas are affected by very high denudation rates, due to short seasonal streams ("fiumare") characterized by high transport capability, favoring very high sedimentation rates on the continental shelf (GALLIGNANI, 1982; CHIOCCI et al., 1989), as well as by the accumulation of 4000$5000 \mathrm{~m}$ of Plio-Pleistocene marine sediments in the Paola intra-slope basin (BARONE et al., 1982).

The continental shelf is extremely narrow (2$10 \mathrm{~km}$ wide), steep (up to $2-2.5^{\circ}$ ) and affected by instability phenomena (GALLIGNANI, 1982). The thickness of the sediments deposited on the continental shelf since the last glacial maximum (LGM; 20,000 years B.P.) is the greatest of the entire Tyrrhenian margin (up to $65 \mathrm{~m}$ ). Similar thicknesses can only be found in the areas located close to the mouths of the major rivers, such as the Tiber and the Volturno, along the Tyrrhenian coast.

Pre-LGM deposits consist of siliciclastic prograding units of Plio-Pleistocene age, mainly formed during lowstand and forced regressive stages (CHIOCCI; ORLANDO, 1995).

\section{Methodology}

The data analyzed in this study were acquired on two oceanographic cruises organized by the CNR (National Research Council). The first cruise was undertaken for mining purposes at the northern and southern extremities of the study area (see CHIOCCI et al., 1989). The second cruise investigated the central part of the study area. High-resolution single-channel seismic reflection profiles were collected on strike lines (parallel to the coast) and dip lines (perpendicular to the coast); dip lines start at about $0.5-2 \mathrm{~km}$ from the shore and run E-W, down to the shelf break located at about 120-150 m w.d. (Fig. 1c). The positioning systems used during the data acquisition were the GPS for the central part (i.e., between Paola and Cape Suvero) and the Loran C for the northern and southern sectors. Some problems arose during the integration of the two datasets, mainly because of the distortion of the Loran $\mathrm{C}$ data due to the proximity to the Catanzaro master station.

During the 1993 cruise, $1 \mathrm{~kJ}$ Sparker (SPK) recordings were made with 250 and 500 ms sweeps using a $200-1,000 \mathrm{~Hz}$ band pass filter; $3.5 \mathrm{kHz}$ SubBottom Profiler lines (SBP) were recorded with a 125 ms sweep. During the 1985 survey and part of the 1993 surveys, the Uniboom (UNI) was used instead of the SPK, with a recording sweep of $250 \mathrm{~ms}$ and a 500$3,000 \mathrm{~Hz}$ band pass filter. All profiles were acquired analogically and represented in variable density.

\section{RESUlts \\ Methodological Aspects}

Five seismic profiles acquired on a transect perpendicular to the coast off the Savuto River, using 
different seismic sources (Sparker 4,500 joule, Sparker 1,000 joule, Sparker 500 joule, Uniboom, Sub Bottom Profiler), are shown in Figure 1. The comparison of the profiles highlights the different degrees of resolution/penetration due, on the one hand, to the high-resolution capability and low penetration of frequencies of thousands of $\mathrm{Hz}$ and, on the other, to the relatively low-resolution capability and relatively high penetration of frequencies of hundreds of Hz. This well-known relationship and some intrinsic characteristics of the seismic sources (ringing of the SPK, mono-frequency and electronic ringing of the SBP) account for the different seismic responses to the same stratigraphic-tectonic features. Specifically:

1) The erosive surface (indicated by LGM-U in Fig.

2 ) which cuts the clinoforms with a sharp angular unconformity generates a completely flat reflector in Figures $2 \mathrm{a}$ and $\mathrm{b}$; in Figure $2 \mathrm{c}$ the SPK 500J shows a slight roughness, corresponding to a bedrock high, on the right side of the profile; in Figure $2 \mathrm{~d}$ this last zone corresponds to a rough area with irregularities of moderate size ( $3 \mathrm{~m}$ in height within a distance of $10-30 \mathrm{~m}$ ); in Figure 2e the surface is not reached. In this case, the best description of the feature is given by the UNI system (Fig. 2d), seeing that the Sparker sources do not provide an adequate horizontal resolution, due to the low frequency content, and the SBP does not provide enough penetration.

2) The Transgressive Systems Tract, i.e. a lenticular sedimentary unit making up the lower part of the Postglacial wedge (indicated by the arrows in Fig. $2 \mathrm{~d}$ and $2 \mathrm{e}$ ), lies directly on the erosional surface and is over 15 meters thick. It is quite visible in Figure 2d, and partially observable in $2 \mathrm{c}$, but not in $2 \mathrm{a}$ or $2 \mathrm{~b}$; in Figure $2 \mathrm{e}$, only the top of the unit is clearly evident. The acoustic facies is not detectable with respect to the rest of the postglacial deposits in Figures $2 \mathrm{a}, \mathrm{b}$ and $\mathrm{c}$. In Figure $2 \mathrm{~d}$, there is an evident lack of internal reflections with respect to the overlying deposits, in Figure 2e, this difference is far clearer and the lenticular unit appears acoustically transparent. In this case, the UNI (Fig. 2d) is the instrument that best shows the internal geometry while SBP (Fig. 2e) has a better discrimination capability due to the difference in acoustic facies.

3) A fault in the Pleistocene deposits causes the uplift of the outer shelf sector (arrows on the left side of profile $2 b$ ) and is clearly visible in $2 b$ and $2 \mathrm{c}$ where an offset of 3-4 $\mathrm{m}$ is detected. It appears as an irregularity in the stratification and cannot be interpreted as a fault in $2 \mathrm{a}$ and $2 \mathrm{~d}$, while it is not visible at all in 2e. In this case, the instrument that best depicts the feature is the low-energy SPK (Fig. 2c).
4) The strata within the bedrock (left side of the profiles) and below the erosional surface on the right side (indicated by the letter B in Fig. 2b) are not depicted by any instrument other than the SPK $4.5 \mathrm{~kJ}$ (Fig. 2a) and only partially by the SPK $1.0 \mathrm{~kJ}$ (Fig. 2b), the latter depicting deep faulting in the lower and central part of the profile not visible in Figure 2a. In this case, contrary to what had been expected, the SPK 4.5 $\mathrm{kJ}$ is the instrument that best defines the stratigraphic features, and the SPK $1.0 \mathrm{~kJ}$ is that which best characterizes the structural ones.

In Figure 3 a synthesis of the seismostratigraphic features depicted by the different seismic sources is represented by the width of the different lines.

The following observations describe, beyond the theoretical potential of each seismic source (for this type of analysis see, for example, Trabant, 1984), the kind of stratigraphic information that each source can provide for the geological interpretation of geophysical data, as a consequence of the characteristics and operating procedures of the seismic equipment.

The 3.5 kHz Sub-Bottom Profiler offers an excellent acoustic image within the first 5-6 meters below the sea floor with a very high-resolution (around $0.5 \mathrm{~m}$ ). Because of the high frequencies and low energy, the penetration is strongly dependent on the lithology and is never greater than $20 \mathrm{~m}$. With respect to the other sources, the SBP is well able to differentiate among the acoustic facies even in the case of very slight differences in the physical characteristics of the deposits. This is due to the fact that the SBP uses low-energy (5 Joules) and highfrequency $(3.5 \mathrm{kHz})$ which causes great differences in scattering effect due to changes in sediment type (e.g., the presence of sand and gravel). Moreover, it must be remembered that, because the SBP has a very narrow band-width, the energy loss occurs rather uniformly across the entire band of the signal. These facts allow for an appreciable difference in penetration, even for slight variations in the homogeneity of the sediments. On one hand this type of behavior offers an excellent discriminating capability among lithologies which have only slight physical differences. On the other hand, it often precludes univocal interpretation in that the amplitude of the reflections and acoustic facies may be due as much to the characteristics of the sediment as to the weakness of the signal, as a result of its absorption by the overlying layers. As a result, it is difficult to achieve accurate 3D reconstructions of the subsurface acoustic facies solely with the use of the SBP. Indeed this fact becomes even worse when the limited penetration capability of the SBP signal is taken into consideration. However, this situation does not hold good for the other sources as they generally 
have a wider band-width and the absorption is distributed along the spectrum of frequencies as it increases with increasing frequency. Thus, at least a part of the signal is transmitted downwards thereby producing a greater lateral continuity of the reflectors.
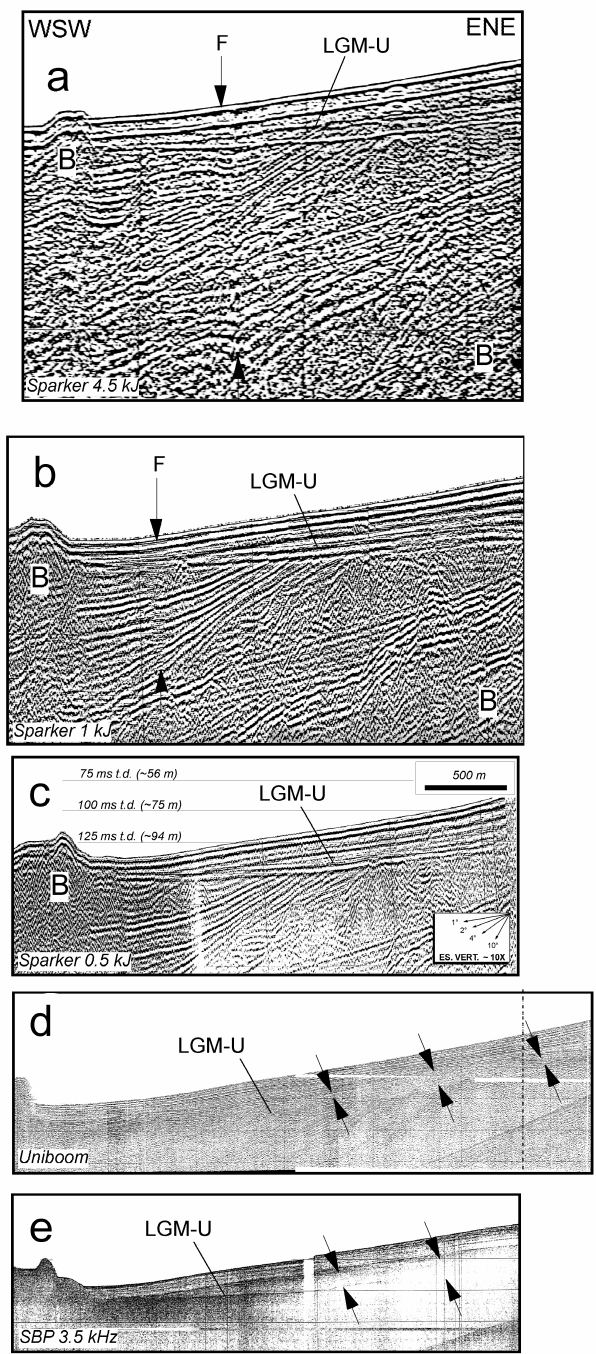

Fig. 2. Single-channel seismic profiles along a transect normal to the coast off the Savuto River (see Fig. 1 for location): a) Sparker 4,500 joule; b) Sparker 1,000 joule; c) Sparker 500 joule; d) Uniboom; e) Sub Bottom Profiler; the main instrumental characteristics are summarized in Table 1. All of the profiles were plotted using the same horizontal and vertical scales. Minor differences among profiles are due to imprecision in the navigation route (the maximum difference is estimated to be $<50 \mathrm{~m}$ ) and to data positioning (about 100 m). LGM-U is the Last Glacial Maximum unconformity cutting the clinoforms which constitute the continental shelf. The arrows in b) indicate a normal fault (F) raising the outer shelf; the arrows in d) indicate the base and top of the Transgressive Systems Tract.
The Uniboom provides a resolution that is comparable to that of the SBP, but with a significantly greater penetration (up to about $100 \mathrm{~m}$ ). Obviously, as is also true for the other sources, there is a loss of resolution with depth, due to the absorption of the higher frequencies. The UNI is able to pick out even very thin seismostratigraphic units and to define the characteristics of the internal reflectors and reciprocal geometry. On the other hand, the acoustic facies is not as well differentiated by UNI as it is by the SBP (at least as regards the analogical data acquisition used in this study), because the signal is often saturated or gives little variation in amplitude.

As far as variable energy Sparker sources are concerned, passing from the SPK of 4,500 joule to 1,000 joule to 500 joule, the average resolution varies, respectively, from $15 \mathrm{~m}$ to $10 \mathrm{~m}$ to $5 \mathrm{~m}$ (Table 1 ). In fact, the Sparker source is characterized by a strong "bubble effect", generating a "ringing" of several milliseconds which increases with the energy level (up to about $15 \mathrm{~m}$ for the 4,500 joule Sparker). This acoustic effect greatly reduces the vertical resolution, especially where high variations in acoustic impedance, such as that produced by the sea floor interface or by bedrock/sediment interfaces, are present. The SPK seismic profiles collected at different power levels may, therefore, appear to be very different, showing a tendency towards a homogenization of the acoustic facies as energy increases. On the other hand, as the sparker sources are characterized by high energy and low frequency, they can depict reflectors at great depth, even in zones characterized by a lack of penetration on the Uniboom and SBP profiles. In practice, the SPK sources, even though they reach depths greater than those of the other sources, are often of limited resolution for the three-dimensional reconstruction of the shallow subsurface.

The comparison among the results obtained using different seismic sources (with regard to the resolution, penetration and acoustic facies) shows that the UNI is the most effective source for shallow subsurface investigation as it provides high-resolution together with adequate penetration and good lateral continuity of the seismic horizons. Further, the finest seismostratigraphic characterization of recent deposits is achieved by the coupling of either Uniboom or Sparker to the Sub-Bottom Profiler. The coupling of these seismic sources provides high resolution (about $0.5 \mathrm{~m}$ in the most recent units) as well as adequate penetration (100-200 m) and detailed lithological information derived from the acoustic facies.

\section{Interpretative Aspects:}

The Postglacial Depositional Sequence

The Postglacial depositional sequence (PDS) was investigated in detail by coupling the high vertical 
resolution given by the single channel seismics $(1 \mathrm{~kJ}$ Sparker or Uniboom and Sub-Bottom Profiler) to a narrow spacing network of seismic profiles $(0.5-2$ $\mathrm{km})$. It was thus also possible to reconstruct threedimensionally shallow-depth seismic units, only a few milliseconds thick, in areas where these units have low lateral continuity as they are interrupted by the morphological irregularities of basal surfaces.

For the purpose of interpretation, the seismic units have been defined according to the principles of seismic stratigraphy (VAIL et al., 1977), in the light of their external form, the internal configuration of the reflectors and the basal and top terminations.

In order to correlate the units even in complex areas (e.g. areas that are separated by morphological highs which interrupt the lateral continuity of units), their acoustic facies were also taken into consideration (essentially amplitude and continuity of reflectors). In fact, these units have a fairly uniform acoustic facies (or at least variable only over distances greater than those of the profile spacing). Finally, the data relating to the inner structure of the postglacial wedge were interpreted in accordance with sequence-stratigraphy principles (POSAMENTIER; VAIL, 1988; VAN WAGONER, et al., 1988; POSAMENTIER et al., 1992; TESSON et al., 1993; HERNANDEZ-MOLINA et al., 2000; TRINCARDI; CORREGGIARI, 2000; LERICOLAIS et al., 2000).

Table 1. Main characteristics of seismic sources. Gray cells refer to data actually measured on seismic profiles.

\begin{tabular}{llllll}
\hline \hline \multicolumn{1}{c}{ Seismic source } & \multicolumn{1}{c}{ SBP 3.5kHz } & \multicolumn{1}{c}{ Uniboom } & SPK 0.5kHz & \multicolumn{1}{c}{ SPK1000 } & \multicolumn{1}{c}{ SPK4500 } \\
\hline source type & piezoelectric & electromechanical & electric & electric & electric \\
power (joule) & 5 & 300 & 500 & 1000 & 4500 \\
pass band (Hz) & - & $500-3.000$ & $400-2.000$ & $200-1.000$ & $60-400$ \\
ping rate (s) & $>0.62$ & $>0.125$ & $>0.25$ & $>0.5$ & $>1$ \\
horiz. sampling.(m) & 0.16 & 0.3 & 0.7 & 1.3 & 2.6 \\
recording sweep (ms) & 125 & 250 & 250 & 500 & 500 \\
vert. resolution (m) & $\sim 0.5$ & $\sim 0.5$ & $\sim 5$ & $\sim 10$ & $\sim 15$ \\
penetration $(\mathrm{m})$ & $<20$ & $\sim 100$ & $\sim 100$ & $\sim 200$ & $300 / 400$ \\
\hline
\end{tabular}

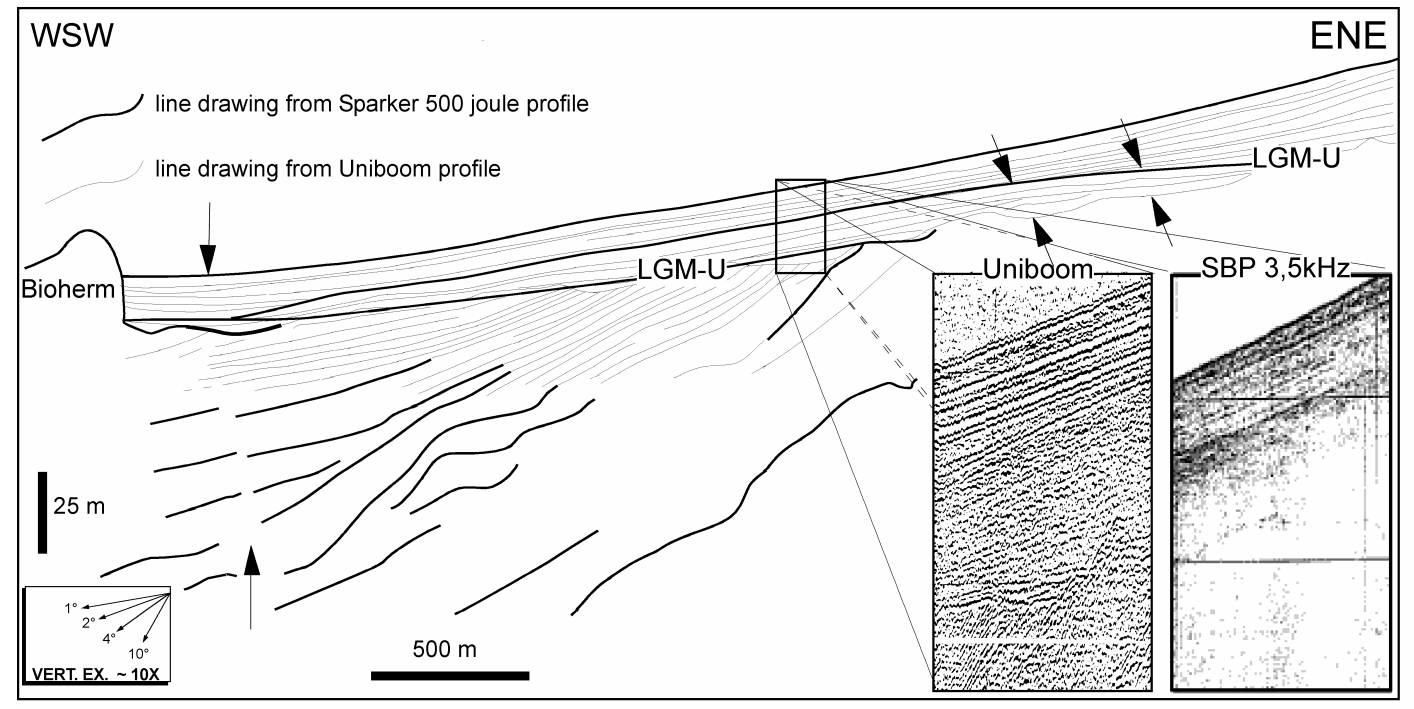

Fig. 3. Line drawing with a synthesis of the interpretative results produced by different seismic sources; LGM-U: Last Glacial Maximum unconformity; F: fault; B acoustic basement. 
The interpretation of the seismic data permitted a definition of the PDS depicted in the shallow subsurface and bounded at its base by an erosional unconformity (i.e., the Last Glacial Maximum unconformity). The latter has a regional extent and represents the youngest erosional unconformity detectable in the subsurface (Fig. 4). Similarly to those of other areas, these characters, as well as the correspondence between the maximum depth of the erosional unconformity and the depth of the eustatic minimum reached during the last glacial period (about $-120 \mathrm{~m}$ ) correspond to those of the Last Glacial Maximum unconformity (LGM-U) with a maximum age of about 20,000 years B.P. The overlying sedimentary succession represents part of a fourth-order depositional sequence (sensu Posamentier and Vail, 1988), incomplete and still evolving, made up of a transgressive systems tract and a high-stand systems tract still in the process of formation (Fig. 4 and 5).
The LGM erosional unconformity (LGM$\mathrm{U}$ ) is easily detectable throughout the area because it is a high-amplitude reflector which truncates the underlying Plio-Pleistocene prograding clinoforms (Fig. 2b and 2c) with angular disconformity. Generally the LGM-U is a seaward dipping surface $\left(0.8^{\circ}\right.$ to $3.6^{\circ}$ ), reaching a maximum depth of $150 \mathrm{~m}$; below this depth it loses its erosive character and becomes a conformity surface. The erosion occurred because of the subaerial exposure of the shelf during glacial times. However, the LGM-U is a polygenic surface since it has been reworked by the successive sea level rise (i.e. by the ravinement process; SWIFT, 1968) which occurred between $18-20,000$ and 6-8,000 years B.P.

Landward, at depths shallower than 15-20 m, it is not possible to depict the LGM-U because the seismic signal loses its penetration probably due to the presence of coarse sediments.

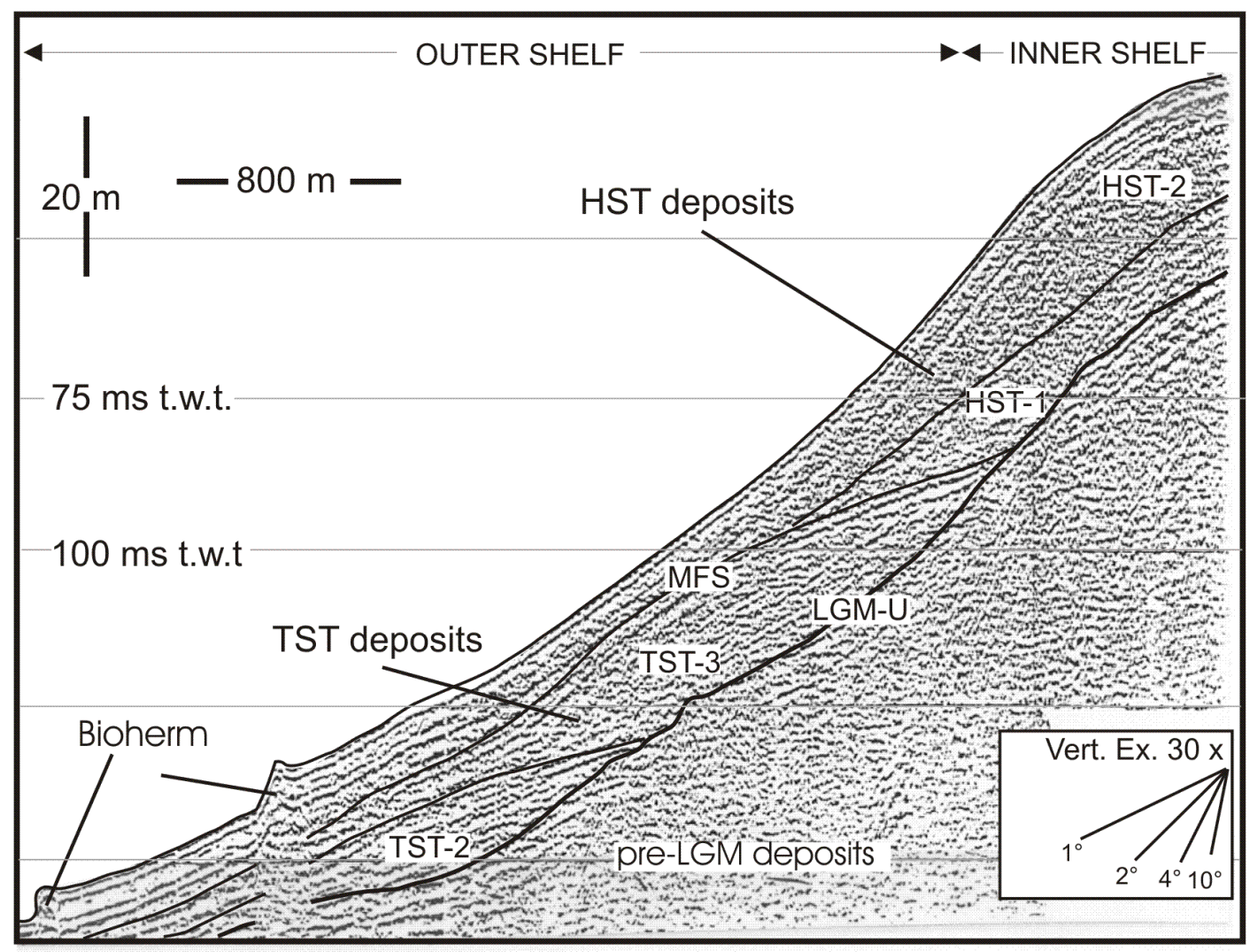

Fig. 4. Sparker 1,000 joule profile offshore Fuscaldo (see Fig. 1 for location). The transgressive systems tract (TST), made up of two parasequences in a retrogradational stacking pattern (TST-2 and TST-3), and the high-stand systems tract (HST), made up of two parasequences with a progradational/aggradational stacking pattern (HST-1 and HST-2), are shown. MFS represents the maximum flooding surface. 

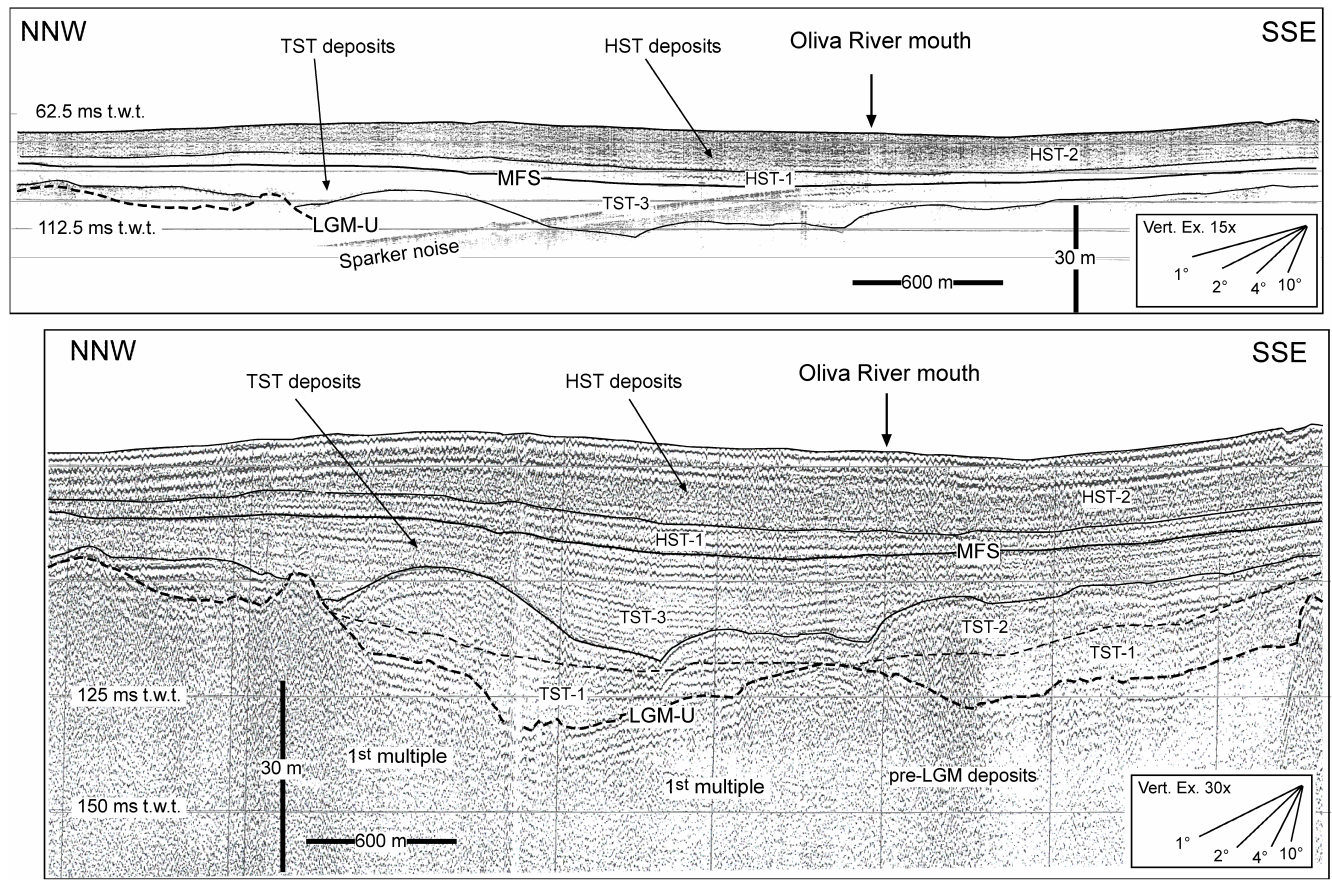

Fig. 5. Sparker and Sub-Bottom strike profiles offshore of the Oliva River mouth (see Fig. 1 for location). In the Sparker profile (lower section) three transgressive parasequences (TST-1, TST-2 and TST-3), with complex geometries and laterally confined by the irregularity of the Last Glacial Maximum unconformity (in particular TST-1 and TST-2), are clearly depicted. Due to the lower penetration of the Sub-Bottom source, the parasequences TST-1 and TST-2 are not depicted (upper section). Conversely, the difference in acoustic facies between the high-stand parasequences HST-1 and HST-2 is enhanced.

In some areas the LGM-U has a rather uneven trend (Fig. 6a) due to the presence of several morphological highs; dredging performed on these highs has recovered biohermal material, though it is very probable that the bioherms developed on preexisting "bedrock" highs.

Only in the areas between Cape Bonifati and Guardia Piemontese, between San Lucido and Amantea and in the Gulf of S. Eufemia the morphology of the LGM-U becomes more regular, with isochrones running sub-parallel to the coast (Fig. $6 a)$.

As has been mentioned previously, the postglacial deposits formed over the past $18-20,000$ years (Fig. 4 and 5) lie on the LGM-U. They are present throughout the shelf with a notable thickness (up to $65 \mathrm{~m}$ ) except in areas where the morphological highs are present (between Guardia Piemontese and Paola, off Amantea, between the Oliva and Savuto rivers and off Cape Suvero). Generally, their thickness reduces toward the shelf edge. The thickness distribution highlights isolated depocenters located at the northern and southern ends of the study area, as well as a continuous wedge in the central part (Fig. $6 b)$. The isolated depocenters are located offshore of the mouths of the main rivers (the Oliva, Amato and Savuto). The depocenters run parallel to the coast and reach a maximum thickness of $50-60 \mathrm{~ms}$ t.w.t. (corresponding to $40-48 \mathrm{~m}$ with a sound speed of about $1,600 \mathrm{~m} / \mathrm{s}$ ). Conversely, the wedge located in the central part of the area is continuous and extends laterally for more than $20 \mathrm{~km}$, reaching the notable thickness of up to 70-80 ms t.w.t. (55-65 m) close to the coast. The wedge is present between S. Lucido and Amantea where the LGM-U is quite regular and where several small streams ("fiumare") are present. At present, these streams carry a very large amount of sediment, drained from the uplifting Coastal Range (Fig. 6c)

As previously mentioned, lower hierarchical order sedimentary units were identified within the PDS (Fig. 4 and 5). Within the inferred Versilian package, the sequence-stratigraphic interpretation allows the definition of a transgressive systems tract made up of parasequences with a retrogradational stacking pattern. These parasequences are succeeded by high-stand systems tracts probably of Holocene age. The high-stand systems tracts can be further subdivided into parasequences arranged in a progradational and aggradational stacking pattern. 


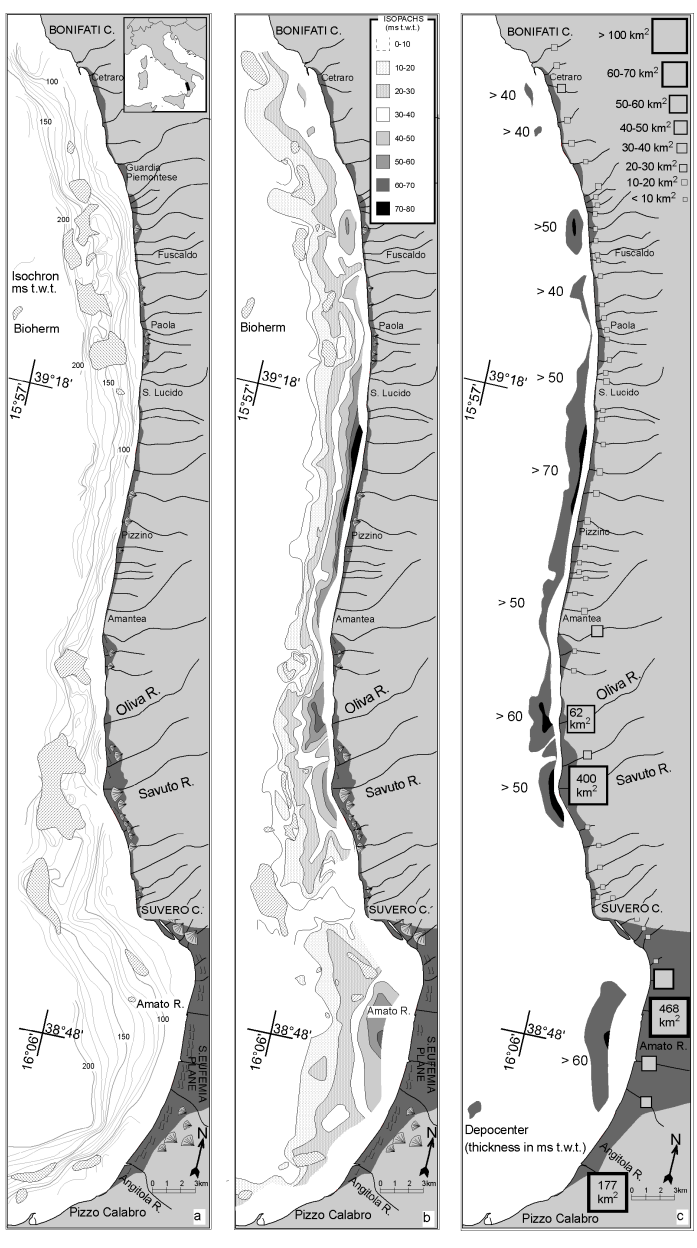

Fig. 6. A) Depth of the Last Glacial Maximum unconformity at the base of the postglacial depositional sequence (contours in $\mathrm{ms}$ t.w.t.); B) thickness of the postglacial depositional sequence (isopachs in ms t.w.t.); C) sketch of the main depocenters of the postglacial deposits and river's drainage basins on land. The continuous wedge extending between $\mathrm{S}$. Lucido and Amantea highlights the greater efficiency in sediment supply of the several very small seasonal streams ("fiumare") relatively to the main rivers (Amato, Savuto and Oliva rivers).

The transgressive systems tract makes up the lower part of the PDS and lies directly on the LGM-U. It consists of up to 3 parasequences that are internally characterized by a number of prograding reflectors (near the coast) or sub-parallel to the basal surface (on the outer shelf). The boundary with the overlying high-stand systems tract is marked by the maximum flooding surface (MFS, Fig. 4). On dip seismic profiles, the MFS is a downlap surface that has a rather sigmoidal profile, or in some cases, a concave-up profile. The transgressive parasequences are bounded by flooding surfaces generally characterized by high-continuity and high-amplitude reflectors and by downlap terminations of the overlying reflectors (Figs 4 and 7). The parasequences boundaries show lower continuity and lower amplitudes and are characterized by lateral variations in amplitude, with respect to the MFS. The transgressive parasequences are laterally confined by the irregularities of the LGM-U, especially influencing the oldest-lower parasequences (Figs 5 and 7). In some cases, the low lateral continuity of the deposits limits the interpretation of the profiles, not allowing the complete correlation of the transgressive systems tract in the various areas of the shelf.

Three-dimensionally, the transgressive systems tract is characterized by a number of isolated depocenters, the most important of which is found offshore of the Oliva River (44 ms t.w.t.) where three parasequences are present (Fig. 5). On the other hand, where the depositional sequence is thinner, only one or two parasequences are present.

The high-stand systems tract is made up of two parasequences, bounded by a non-depositional surface. The lower parasequence lies directly on the maximum flooding surface and shows a constant low amplitude acoustic facies throughout the area (Fig. 7). The upper parasequence shows an extremely variable acoustic facies, especially in its upper part, which varies from a completely transparent facies to a high continuity and high amplitude seismic facies. Off the Savuto River, the upper parasequence is rather thick [20 ms t.w.t. $(\sim 15 \mathrm{~m})$ in a water depth of about $55 \mathrm{~m}$ ] and it is characterized by discontinuous highamplitude internal reflectors which may indicate coarser lithologies linked to the Savuto River delta. The two units described above are characterized by different depositional styles. The lower parasequence is generally prograding and the reflectors become concordant with respect to the MFS only in the external areas of the shelf. By contrast, the upper parasequence shows an almost constant concordance with the underlying deposits.

The distribution of the high-stand deposits is more regular with respect to the transgressive deposits. The high-stand systems tract is in fact continuous over the entire area between Cape Bonifati and Pizzo Calabro, attaining a maximum thickness of $50 \mathrm{~ms}$ t.w.t. (around $40 \mathrm{~m}$ ) offshore of the Savuto River. Morphological highs on the outer shelf hinder the presence of the high-stand systems tract that elsewhere extends as far as the shelf break. The thickness of high-stand sediments diminishes rapidly seaward to a constant thickness of $2-5 \mathrm{~ms}$ t.w.t. $(1.5-4 \mathrm{~m})$ that is maintained out to the shelf break. The geometry of the high-stand deposits is, therefore, wedge-like on the inner shelf, tabular on the outer shelf and wedges out basinward. 


\section{P9}
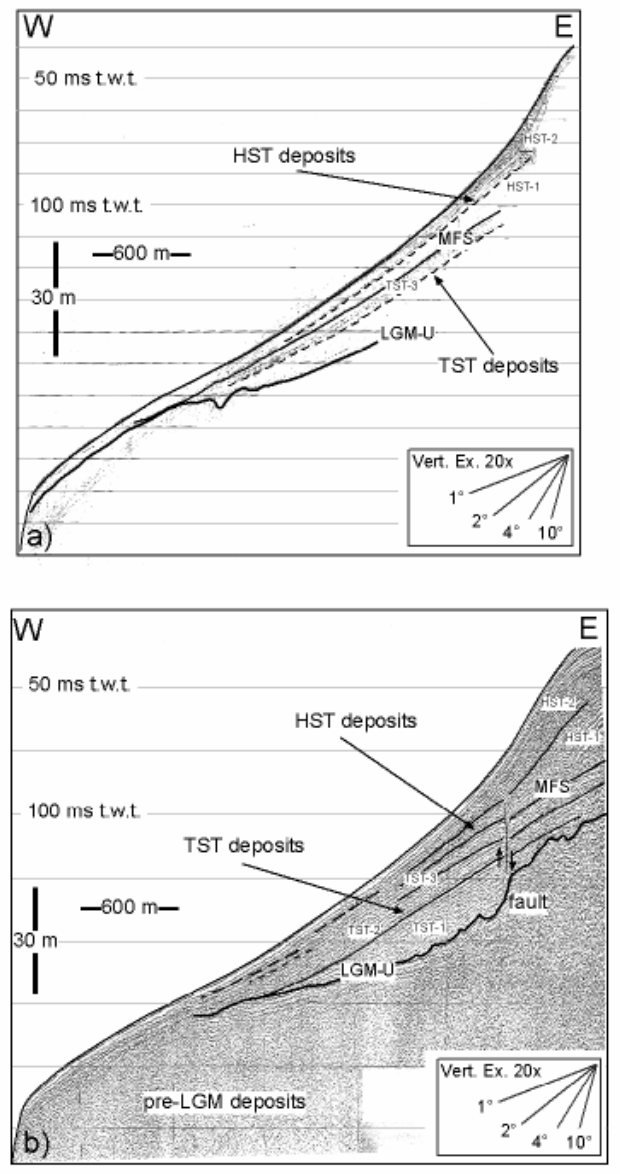

Fig. 7. Sub-Bottom (A) and Sparker (B) dip profiles off the S.Lucido-Pizzino sector. In this area, the TST parasequences partially lose the progradational stacking pattern and are deformed by a fault, that produces an offset of 1-2 $m$ (see the Sparker profile, below in the Figure). The fault affects only the oldest HST deposits and is not detected by the SubBottom profile (above in the Figure).

\section{Discussion ANd Conclusions}

The results of the seismic surveys undertaken on the Calabro-Tyrrhenian continental shelf bring out clearly that, since the last glacial maximum (i.e., since 20000 yrs B.P.), the continental shelf has undergone great paleo-environmental and paleo-geographical changes within a short time interval. The stratigraphic expression of these changes is represented by the Postglacial depositional sequence. The comparison of the stratigraphic reconstruction achieved with those from other high-resolution studies (e.g. CHIOCCI et al. 1989; CORREGGIARI et al., 1996; HERNANDEZ-MOLINA et al., 2000) suggests that the Postglacial depositional sequence is mainly characterized by: 1) thin seismic units (from a few meters to a few tens of meters); 2) the shift of depocentres across the shelf due to variation in accommodation space (e.g., during transgression); 3) the occurrence of units composed of unconsolidated sediments deposited in different environments (e.g., shelf mud overlying relict sands). Within this framework, the degree of resolution, penetration and seismic facies depiction capability may be considered crucial factors in the interpretation, as they systematically control the main steps of stratigraphic interpretation of seismic profiles. Notably, the latter includes the identification and characterization of: 1) bounding discontinuities; 2) key stratal terminations; 3 ) the external form of seismic units, and 4) seismic facies (e.g., reflection geometry, amplitude-continuity of seismic reflections). Analogously, the application of the sequence stratigraphy technique to the study of the shelf stratigraphic architecture is largely affected by these factors. In fact, it can be achieved only through the identification of key horizons (e.g., the sequence boundary and maximum flooding surface) and depositional units (depositional sequences, systems tracts and parasequences). The recognition of the sequence boundary based on high-resolution profiles is usually guaranteed by an adequate sub-bottom penetration. Some exceptions occur on very high resolution profiles imaging thick coarse-grained sediments (sand and gravel) or in the case of low resolution profiles imaging very thin postglacial deposits where the sequence boundary is masked by the "ringing" effect of the seafloor. Moreover, the identification of parasequencies having a few meters to a few tens of meters thickness is achieved only through very high resolution lines, as it depends on the resolution capability of the profiles to detect closely spaced discontinuities and small-scale geometries. The definition of the acoustic facies is the factor most sensitive to the acoustic source used, as intrinsic characteristics or operational settings may greatly affect the amplitude/coherence of reflectors; in fact, a seismic unit may show a different acoustic facies according to the source used to image it.

In detail, the results achieved indicate that, despite the fact that all the seismic sources used are high-resolution equipment, significant differences exist in the information obtained from the respective seismic profiles. Aside from the well known difference in terms of penetration, which demands lower frequencies, and resolution, which requires higher frequencies and greater bandwidths (see for example Mosher and Simpkin, 1999), the capability to differentiate the acoustic facies is also rather variable. On the whole, the Sub-Bottom Profiler provided the 
best results for the acoustic facies characterization of the uppermost units, while Uniboom and Sparker sources, as was expected, produced less adequate results. Among the seismic sources, the Uniboom emerged as the most suitable device to reconstruct the "complete" shallow stratigraphy, as it is able to depict small-scale seismic units $(0.5 \mathrm{~m}$ of vertical resolution in the uppermost units) with depth of penetration up to 100 meters. In agreement with Brizzolari (1980) and Mosher and Simpkin (1999), the results of this study corroborate the full applicability of this seismic source, as Uniboom profiles are highly readable, provide a comprehensive stratigraphic scheme of postglacial deposits along the whole shelf and also contain fundamental data regarding the seismostratigraphic interpretation and the application of sequence-stratigraphy concepts. However, a more detailed and complete seismostratigraphic reconstruction has been obtained either through the interpretation of Sub-Bottom Profiler and Uniboom profiles or from Sub-Bottom Profiler and Sparker profiles. In both cases, the very high frequency and vertical resolution of the Sub-Bottom Profiler provides a detailed reconstruction of the internal structure of the uppermost seismic units (e.g., highstand parasequences), while the considerable penetration of the Uniboom or Sparker (about 100-200 m) allows the reconstruction of key surfaces such as the LGM unconformity and the maximum flooding surface.

The integrated interpretation achieved through Sub-Bottom Profiler-Sparker profiles and Uniboom records allowed a particularly efficient use of sequence-stratigraphy concepts. The application of these concepts to recent Calabrian continental shelf deposits indicates that above the LGM erosional unconformity, a well developed Postglacial depositional sequence is present. This sequence attains the greatest thickness of the entire Tyrrhenian margin (up to $65 \mathrm{~m}$ ). A similar thickness can only be found in areas located close to the mouths of the major rivers along the Tyrrhenian coast (e.g., that of the Tiber; Bellotti et al., 1994). Within the Postglacial depositional sequence, a thick transgressive systems tract and a high-stand systems tract are present. The transgressive systems tract is composed of well defined parasequences arranged in a retrogradational stacking pattern, and bounded by marine flooding surfaces; the greatest number of parasequences (up to three) is to be observed corresponding to the maximum thickness of the systems tract. If compared with other Mediterranean shelves, the transgressive systems tract is seen to be particularly well developed (thickness of up to $33 \mathrm{~m}$ ); in fact, these deposits are usually nearly absent or confined to narrow areas on other shelves (e. g., the Adriatic shelf - Correggiari et al., 1996 - and the central Tyrrhenian shelf - Chiocci, 2000). The overlying high-stand systems tract, bounded at the base by the maximum flooding surface, shows quite uniform characteristics throughout the area. It is made up of a maximum of two parasequences with aggradational or progradational stacking patterns.

The analysis of the thickness distribution of the postglacial depositional sequence shows that the greatest thickness (up to 55-65 m) and volumes do not occur, as had been expected, at the mouths of the main rivers, but rather along a stretch of coast characterized by several small streams (fiumare with small alluvial catchment areas) and with high relief close to the shoreline (i.e., the Coastal Range). Both of these factors promote high sedimentation rates on the shelf, as they assist in providing a large sediment supply from the land. They indicate the greater efficiency of linear sediment sources (streams) than of the point sources (major rivers) in delivering large volumes of sediment to the shelf as well as the important role of high relief close to the coast in facilitating the transport of sediment out on to the shelf. In fact, this last factor implies that sediment is not stored on the coastal plain (or in other subaerial basins). In agreement with Chiocci et al. (1989), a possible example is the case of the Amato River, the largest river in the study area, where the major portion of the sediment produced in the catchment area of which was trapped on the S. Eufemia plain.

\section{ACKNOWLEDGEMENTS}

We thank Professor M. Bernabini for his critical review of this article and all the participants of the oceanographic surveys "Minerva " 85 " and "Urania '93", on which seismic data were collected.

\section{REFERENCES}

BARONE, A.; FABBRI, A.; ROSSI, S.; SARTORI, R. Geological structure and evolution of the marine areas adjacent to the Calabrian Arch. Earth Evol. Sc., v. 3, p. 207-223, 1982.

BELLOTTI, P.; CHIOCCI, F. L.; MILLI, S.; TORTORA, P.; VALERI, P. Sequence stratigraphy and depositional setting of the Tiber delta: integration of high-resolution seismics, well logs, and archeological data.. J. Sedim. Res., v. B64, p. 416-432, 1994.

BRIZZOLARI, E. Possibilità d'impiego della prospezione sismica monocanale per la ricerca di sabbie metallifere. L'industria Mineraria v. 1., 1980.

CHIOCCI, F. L. Depositional response to Quaternary fourthorder sea-level fluctuations on the Latium margin (Tyrrhenian Sea, Italy). In: HUNT, D.; GAWTHORPE, R. L. (Ed.). Sedimentary responses to forced regressions. Geol. Soc. spec. Publ., v. 172, p. 271-290, 2000. 
CHIOCCI, F. L.; ORLANDO, L. Effects of Pleistocene sealevel changes on a highly deforming continental margin, Calabrian shelf, Italy. Boll. Geofis. Teor. appl., v. 37, p. $145,39-58,1995$.

CHIOCCI, F. L.; D'ANGELO, S.; ORLANDO, L.; PANTALEONE, A. Evolution of the Holocene shelf sedimentation defined by high resolution seismic stratigraphy and sequence analysis (Calabro-Tyrrhenian continental shelf). Mem. Soc. Geol. Ital., v. 48, p. 359380, 1989.

CORREGGIARI, A.; FIELD, M. E; TRINCARDI, F. Late Quaternary transgressive large dunes on the sedimentstarved Adriatic Shelf In: DE BATIST, M.; JACOBS, P. (Ed.), Geology of Siliciclastic Shelf Seas. Geol. Soc. spec Soc. Publ., v. 117, p. 155-169, 1996.

COSENTINO, D; GLIOZZI, E. Considerazioni sulle velocità di sollevamento di depositi eutirreniani dell'Italia meridionale e della Sicilia. Mem. Soc. Geol. Ital., v. 41, p. $653-665,1988$

GALLIGNANI, P. Recent sedimentation processes on the Calabria continental shelf and slope (Tyhrrrenian Sea, Italy). Oceanologica Acta, v. 5, n. 4, p. 493-500, 1982.

HERNANDEZ-MOLINA, F. J.; SOMOZA, I.; LOBO, F. Seismic stratigraphy of the Gulf of Cadiz continental shelf: a model for late Quaternary very high resolution sequence stratigraphy and response to sea-level fall. In HUNT D. E.; GAWTHORPE R. L. (Ed.). Sedimentary responses to forced regressions. Geol. Soc., London, spec. Publ., v. 172, p. 329-362, 2000.

LERICOLAIS, G.; BERNÉ, S.; FÉNIÈS, H. Seaward pinching out and internal stratigraphy of the Gironde incised valley on the shelf (Bay of Biscay). Mar. Geol., v. 175, n. $1-4$, p. 183-197, 2001.

MCGEE, T. M. High-resolution seismic profiling on water. Annali Geofis., v. 43, n. 6, p. 1045-1073, 2000.

MOSHER, D. C.; SIMPKIN, P. G. Status and trends of marine high-resolution seismic reflection profiling: data acquisition. Geosci., Can., v. 26, n. 4, p. 174-188, 1999.

POSAMENTIER, H. W.; VAIL, P. R. Eustatic controls on clastic deposition II - Sequence and Systems Tract models. SEPM spec. Publ., v. 42, p. 28-42, 1988.
POSAMENTIER, H.W.; ALLEN, G. P.; JAMES, D. P. Highresolution sequence stratigraphy - the east Coulee delta. J. sedim. Petrol., v. 62, p. 310-317, 1992.

SWIFT, D. J. P. Coastal erosion and transgressive stratigraphy. J. Geol., v. 76, p. 444-456, 1968.

TESSON, M.; ALLEN, G. P.; RAVENNE, C. Late Pleistocene shelf-perched lowstand wedges on the Rhone continental shelf. In: POSAMENTIER, H. W.; SUMMERHAYES, C. P.; HAQ, B. U.; ALLEN, G. P. Sequence stratigraphy and facies associations. Int. Ass. Sedimentologists, spec. Publ., v. 18, p. 183-196, 1993.

TRABANT, P. K. Applied high resolution geophysical methods. Boston: Reidel, 1984. 265 p.

TRINCARDI, F.; CORREGGIARI, A. Quaternary forced regression deposits in the Adriatic basin and the record of composite sea-level cycles. In: HUNT D. E; GAWTHORPE, R. (Ed.) . Sedimentary responses to forced regressions. Geol. Soc., London, special Publ., v. 172 , p. $245-269,2000$.

VAIL, P. R.; MITCHUM JR; TODD, G. R.; WIDMIER, J.M.; THOMPSON, S.; SANGREE, J.B. Seismic stratigraphy and global changes of sea level. AAPG Mem., v. 26, p. 49-205, 1977.

VAN WAGONER, J. C.; POSAMENTIER, H. W.; MITCHUM, R. M.; VAIL, P. R.; SARG, J. F.; LOUTIT, T. S.; HARDENBOL, J. An overview of the fundamentals of sequence Stratigraphy and key definitions. In: C. K. WILGUS E. A. ET AL., (Ed.). Sealevel changes: an integrated approach. SEPM spec. Publ., v. 42, p. 39-46, 1988.

VERBEEK, N. H.; MCGEE, T. M. Characteristics of highresolution marine reflection profiling sources. J. appl. Geophys., v. 33, p. 251-269, 1995.

WESTAWAY, R. Quaternary uplift of Southern Italy. J. geophys. Res., v. 98, n. B12, p. 21741-21772, 1993.

(Manuscript received 21 August 2009; revised 01 January 2010; accepted 06 May 2010) 